\title{
Cocconeis napukensis sp. nov. (Bacillariophyceaea) from Napuka Atoll (South Pacific) and lectotypification of Cocconeis subtilissima MeISTER
}

\author{
Catherine RiauX-Gobin ${ }^{1,2 *}$, Pierre Compère ${ }^{3}$, Michel Coste ${ }^{4}$, François Straub $^{5}$ \\ \& Lukas TАхвӧск ${ }^{6}$
}

\author{
${ }^{* 1}$ CRIOBE-USR 3278 CNRS-EPHE-UPVD, \\ ${ }^{2}$ Laboratoire d'Excellence 'CORAIL', Perpignan, France; *Corresponding author e-mail catherine.gobin@, \\ univ-perp.fr, \\ ${ }^{3}$ Botanic Garden Meise, Domein van Bouchout, 1860 Meise, Belgium; e-mail: pierre.compere@br.fgov.be \\ ${ }^{4}$ IRSTEA, 50 avenue de Verdun, 33612 Cestas, France; e-mail: michel.coste@irstea.fr, \\ ${ }^{5}$ PhycoEco, Rue des XXII-Cantons 39,La Chaux-de-Fonds, Suisse; e-mail: fstraub@phycoeco.ch \\ ${ }^{6}$ Institute of Systematic Botany, University of Zürich, Zürich, Switzerland; e-mail: lukas.taxboeck@systbot. \\ uzh.ch
}

\begin{abstract}
A 2012 microphytobenthos survey from coral reef environment at Napuka Atoll (Tuamotu Archipelago, South Pacific) focussed on diatom assemblages. Atolls are tropical carbonate, productive ecosystems, with a fast turnover, from which benthic diatom floras are poorly known. When compared to younger volcanic islands from the same area, Napuka shows a poor colonisation by benthic diatoms. Although normally rare, Achnanthales occur in the assemblages from Napuka. In the tidal zone, marine debris of sponge origin were colonized by several taxa, among others a small-celled Cocconeis here described as C. napukensis sp. nov. The new taxon has some likeness to Cocconeis subtilissima MeIster and to C. vairaensis Ricard. Original drawings and type material are examined when available. A lectotypification and an emended description of Cocconeis subtilissima are proposed, along with the description of Cocconeis suzukii sp. nov. and Cocconeis meisteri sp. nov. from Meister type material. The morphological features of $C$. napukensis are investigated with scanning electron miscroscope (SEM) and light microscope (LM). Until now C. napukensis has not been found in the other investigated sites of Tuamotu and Society Archipelagos.
\end{abstract}

Key words: Cocconeis spp., Cocconeis subtilissima MeISTER typification, Napuka Atoll, South Pacific Abbreviations: LM: light microscope, SEM: scanning electron microscope, RV: raphe valve, SV: sternum valve, RVVC: raphe valve valvocopula; SVVC: sternum valve valvocopula

\section{INTRODUCTION}

The atolls of Napuka $\left(14^{\circ} 10^{\prime} 7^{\prime \prime} \mathrm{S}, 141^{\circ} 13^{\prime} 56^{\prime \prime} \mathrm{W} ; 12\right.$ $\mathrm{km}^{2}$, Fig. 1) and Tepoto North (14 $08^{\prime} \mathrm{S}$; $141^{\circ} 24^{\prime} \mathrm{W}$; $2 \mathrm{~km}^{2}$ ) are located in North Tuamotu (Fig. 1), 450 $\mathrm{km}$ South of Marquises Islands. The latter atolls are isolated in a vast oceanic zone, justifying the name 'Îles de la Désolation' or 'Îles du Désappointement', with their only accompaniment Puka Puka, lying 272 $\mathrm{km}$ southeastwards. The westerly South Equatorial Current (SEC) (TABATA 1975; Rougerie et al. 1997) prevents Napuka from being directly influenced by other islands and reinforces its geographic isolation. Ornithological studies report Acrocephalus atyphus flavidus Cibois \& Thibault (2005) to be endemic to Napuka. Neither hydrological studies nor taxonomical surveys of microalgae are available for Napuka, while the hydrology and phytoplankton at Takapoto, a nearby atoll of West Tuamotu (Fig. 1), are documented
(Sournia \& Ricard 1975, 1976; Magnier \& Wauthy 1976; RiCARD et al. 1979). Napuka and Tepoto North have no direct communication with the ocean, with several 'hoas' (shallow channels between 'motus' coral sand islands-) permitting intermittent exchange with the open ocean. An endo-upwelling theory explaining the apparent contradiction between the high productivity of South Pacific atolls and the oligotrophy of the surrounding ocean was formulated by ROUGERIE \& Wauthy (1986): the atoll's lagoon is fed by deep interstitial waters enriched with nutrients. Subsequent studies (CHARPY-RoubAud et al. 1990; LECLERC 1998; CHARPY 2001) support a different theory: the advective supply of nutrients by the ocean, combined with a high turnover, explains the nutrient status of the atoll's lagoon. Organic matter i.e., aggregates, were also shown to constitute a substantial contribution to the trophic systems within the atoll's lagoon (MARSHALL 1965). Nevertheless, the Chlorophyll $a$ concentration 
is higher in the lagoon's phytoplankton than in the adjacent ocean (KRASNICK 1973; SOURNIA \& RiCARD 1975; RICARD et al. 1979 and references therein, HATCHER 1997). The gross primary production of atolls is high (SOURnia \& RicARD 1975; sournia 1977 and references therein) but with diatoms playing a minor role among microalgae (RICARD et al. 1979). At Napuka (Tuamotu) and Tetiaroa (Society) the marine benthic diatoms are relatively rare while they are abundant in high volcanic islands such as Tahiti and Moorea (pers. obs). On the other hand, dinoflagellates (STANCA et al. 2013) and Coccolithophoridae are dominant on atolls among microalgae, even if less diversified than diatoms (RICARD 1979, and pers. obs.). In the South Pacific Ocean the benthic diatoms (linked to sediments and macroalgae) from atoll's lagoon are dominant versus typically planktonic ones (RICARD 1979, and refs therein).

During the CORal reef DIAtoms (CORDIA) 2012 project, the Achnanthales flora of Napuka was investigated with a particular focus on Cocconeis, a genus pertaining to this order. A small-celled Cocconeis taxon first caught our attention and is here described as new: Cocconeis napukensis sp. nov. The latter taxon is compared to C. subtilissima MEISTER (1935), from which several later on definitions seem contradictive.

\section{Materials And Methods}

Materials used in this study are derived from three sources: 1) Friedrich Meister's type material from Nagasaki, Japan (Fig. 1), 2) M. Voigt's slide collection labelled 'Nagasaki off shells' and 3) a recent marine sample from Napuka Atoll, South Pacific, Tuamotu Archipelago.

Meister's type material: F. Meister's slides are housed in Herbarium of the University of Zürich (Switzerland). The slides 'Nagasaki 3409000' to '01', '03' to '08', '10' to '11' to ' 17 ' have been examined (Fig. 1). According to notes accompanying the sample preparation by F. Meister, the first numbers assign the year of preparation, the third and fourth number the month, and the last three numbers are sequential numbers. F. Meister's hand written notes assign these slides to the shell of a marine snail from Nagasaki ('Nagasaki, Japan, auf Meeresschnecken. verunreinigt mit Süsswasserformen', 'Nagasaki, Japan, on marine snail, contaminated with fresh water forms'). These slides are supposed to contain Cocconeis subtilissima MeIster (see MeIster 1935). Some Meister's notes roughly indicate the position of remarkable taxa on the slides. Unfortunately no indication concerning Cocconeis subtilissima, but a new Cocconeis is indicated as present on the sector 'c' of the slide 3409000 ('Cocconeis $\mathrm{n}$. sp.').

Voigt's slide collection: Several of M. Voigt's slides have been prepared from the same sample ('Nagasaki off shells', 22045-46-47) and some other slides ['Nagasaki on shells', 22072(35)-77(35), 22074(35) have probably been prepared in 1935, and most probably from the same sample]. These slides are housed in Dübendorf (Switzerland) and they have been studied. Hand notes by M. Voigt indicate which taxon was found in which slide. Here again, there was no
Cocconeis subtilissima. Nevertheless, the slide 22045 was examined with particular attention, since it was pointed out by M. Voigt to contain Cocconeis trachyderma F. MeIster, a new species appearing together with Cocconeis subtilissima (see Meister 1935).

Napuka Atoll material (South Pacific, Tuamotu Archipelago): During a 2012 expedition (Coral Reef DIAtoms, CORDIA) at Napuka $\left(12 \mathrm{~km}^{2}\right)$ several marine and lagoon sites were sampled, particularly tidal debris of sponge origin (15NPK7-2, $\left.14^{\circ} 10.702 \mathrm{~S}, 141^{\circ} 15.949 \mathrm{~W}\right)$ collected from the intertidal bed rock, close to the Napuka airstrip.

Napuka Atoll material preparation: The sample was preserved in formaldehyde (10\% final concentration). For scanning electron microscope (SEM) examination, the sample was filtered through $1 \mu \mathrm{m}$ Nuclepore filters and rinsed twice with deionised (milliQ) water to remove salts. Filters were air-dried and mounted onto aluminum stubs before coating with gold-palladium alloy (EMSCOP SC 500 sputter coater) and examined with a Hitachi S-4500 SEM operated at $5 \mathrm{kV}$ (C2M, Perpignan University, France). For light microscope (LM) examination, the sample was washed with distilled water to remove salts, treated with $30 \% \mathrm{H}_{2} \mathrm{O}_{2}$ for $2 \mathrm{~h}$ at $70^{\circ} \mathrm{C}$ to remove organic matter, rinsed several times in distilled water, alcohol-desiccated and mounted on glass slides using $\operatorname{Hyrax}^{\circledR}$ (O. Romero pers. com.). Diatom slides were examined with a Zeiss Axiophot 200, with differential interference contrast (DIC) optics and photographed with a Canon PowerShot G6 digital camera (CRIOBE-Perpignan University, France).

The LM illustration of the new taxon from Napuka does not give a complete overview of its particular features, i.e., the sternum valve (SV) striation, the exact pattern and number of axial rows of alveoli and the valvocopulae. Therefore, according to Article 40.2 of the International Code of Nomenclature (McNeIL et al. 2012) we designated the SEM stub as the holotype showing the best diagnostic features of the new species. Although it is a challenge to
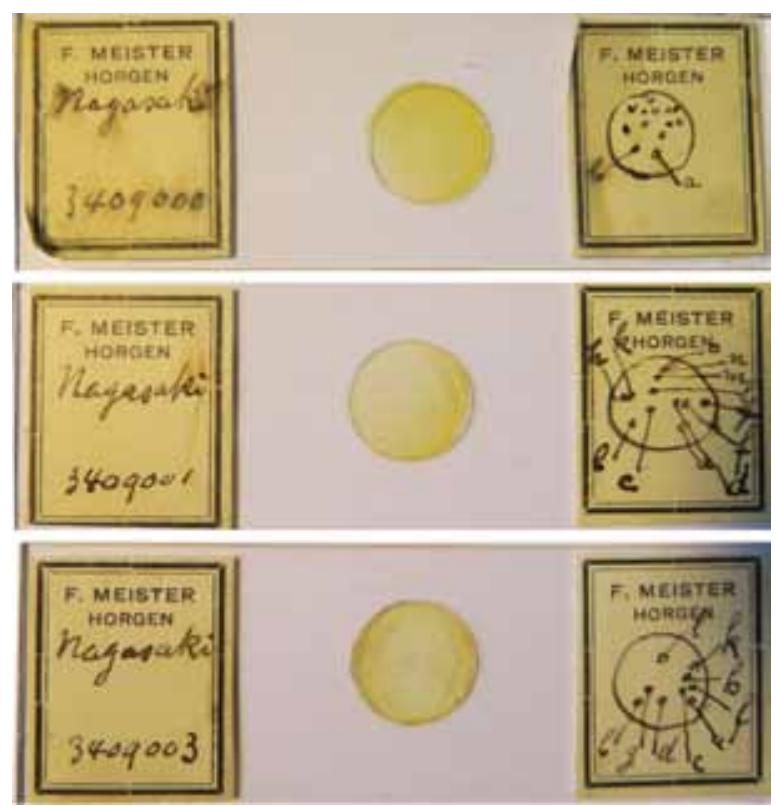

Fig. 1. Illustration of F. Meister's slides "Nagasaki 3409000" (upper), "Nagasaki 3409001" (middle), "Nagasaki 3409003" (bottom, Cocconeis subtilissima MeIsTER Lectotype), housed in Herbarium of the University of Zürich (Switzerland). 
permanently preserve specimens on stubs, they are referenced and kept in an air-dried container at CRIOBE-Perpignan University, France. Isotypes are designated from slides made from the same sample in which the new taxon was observed. All morphometric data are presented in Table 1.

Terminology and abbreviations: Various terminologies have been proposed for the order Achnanthales SILVA. As previously proposed, in particular by RIAUX-GoBIN et al. (2013), and following the Greek origin of the word 'sternum', it is proposed to designate the valve with a raphe as the raphe valve (RV) and the valve without a raphe as the sternum valve (SV). For the description of the frustule and its parts, terminology follows Anonymous (1975), Ross et al. (1979) and Round et al. (1990).

\section{Results}

Even if quantitatively rare, some Achnanthales are present in marine environments of Napuka, particularly in 15NPK7-2, with several species shared with the assemblages of Tahiti and Moorea Islands. The complete Cocconeis assemblage from Napuka, with several unique taxa, will be detailed elsewhere (RIAUXGobin et al. submitted). A new Cocconeis species, closely resembling Cocconeis subtilissima MEISTER sensu SuzuKi et al. (2000) was found abundantly in 15NPK7-2 and was present in some other Napuka samples, while being absent in other areas yet to be studied in the South Pacific (pers. obs.).

We first redefine Cocconeis subtilissima from F. Meister's type material and present two related new taxa, Cocconeis suzukii and Cocconeis meisteri, from the same assemblage from Nagasaki, and finally we present Cocconeis napukensis sp. nov. from the South Pacific.

\section{Meister's type material and Voigt's slide collections ('Nagasaki off shells')}

Cocconeis subtilissima MeISter (1935, p. 99, figs 6162, reproduced in our Figs 6-7), LM (Figs 13-20, Table 1)

Lectotype (designated here): F. Meister's slide 'Nagasaki 3409003'(Fig. 1) housed in Herbarium of the University of Zürich (Switzerland). Lectotype specimen illustrated in Figs 13 (RV)-14 (SV).

Lectotype remarks: None of F. Meister's slides is annotated as containing Cocconeis subtilissima. Nevertheless as indicated by MEISTER (1935), the sample and the corresponding labelled slides 'Nagasaki off shells' from 1934 might contain Cocconeis subtilissima. The notes about the slide 3409000 refer to a Cocconeis n. sp. from sector 'c', but the $C$. subtilissima specimen found on this slide (and not from sector ' $c$ ') is inconclusive because of the SV. On the other hand, Figs 13-14 illustrate a specimen of $C$. subtilissima showing both valves relatively accurately. Lectotype locality: Nagasaki, Japan (from the shell of a marine snail).

Translation of the original German diagnosis: Valve elliptical, $28 \mu \mathrm{m}$ long, $14 \mu \mathrm{m}$ wide. Raphe valve with 23 radial transapical striae in $10 \mu \mathrm{m}$, raphe markedly sigmoid, axial area very narrow, central area roundish, small. Rapheless valve with 34 slightly radial transapical striae, interrupted by an apical hyaline band in the mid-hemivalve. This band is irregularly defined. Axial area narrow, more or less thin, narrower in midvalve. fig. 61-62. Nagasaki, very scarce.

Our examinations (LM, $\mathrm{n}=11)$ : $27.7 \pm 1.9 \mu \mathrm{m}$ long; $12 \pm 0.8 \mu \mathrm{m}$ wide

Stria densities: $>35$ (difficult to discern) SV str. in 10 $\mu \mathrm{m} ; 26.18+1.17 \mathrm{RV}$ str. in $10 \mu \mathrm{m}$

$\mathrm{L} / \mathrm{W}: 2.1 \pm 0.1$

Emended description: Valve oblong-elliptical to linear-elliptical, with round to blunt apices, RV striae dense, equidistant, radiate in the last third of the valve. Raphe sigmoid particularly clearly at apices, terminal raphe fissures close to the margin distinctly bent in opposite directions, central raphe endings close to each other (Figs 16, 18). Axial area narrow, central area transapically elongated into a short fascia. SV densely striated, each hemivalve has a hyaline apically elongated area splitting the striae in two parts. Axial area relatively large, with almost no constriction in mid-valve.

Remarks: The taxon is relatively rare in the Meister type slides, on the eight Meister's slides observed only 22 specimens were encountered, and only a SV on the two Voigt's slides prepared with the same material. Only 11 specimens were clean enough concerning the RV stria densities (Table 1). The SV striae were almost indiscernible, even with interferential contrast, while F. Meister succeeded in counting $34 \mathrm{str}$. in $10 \mu \mathrm{m}$. The RV fascia described as a small and round central area by MEISTER (1935) is well identifiable in his figure 61 as a black oblong mark.

Cocconeis meisteri RIAUX-GobIn et al. sp. nov. (LM, Figs 21-23, Table 1)

Description: Valve small, elliptical with round apices, RV striae equidistant and radiate. Raphe very slightly sigmoid, terminal raphe fissures close to the margin and slightly bent in opposite directions, central raphe endings robust, relatively close to each other. Axial area narrow, small central area. SV densely striated, each hemivalve shows a hyaline apically elongate area dividing the striae in two parts. Sternum large, clearly constricted in mid-valve (Fig. 22, arrows).

Morphometrics (LM, $\mathrm{n}=17)$ : $20.7 \pm 3.2 \mu \mathrm{m}$ long; $12.7 \pm 2.2 \mu \mathrm{m}$ wide

Stria densities: $34 \pm 3.8 \mathrm{SV}$ str. in $10 \mu \mathrm{m} ; 25.7 \pm 1.7 \mathrm{RV}$ str. in $10 \mu \mathrm{m}$ 


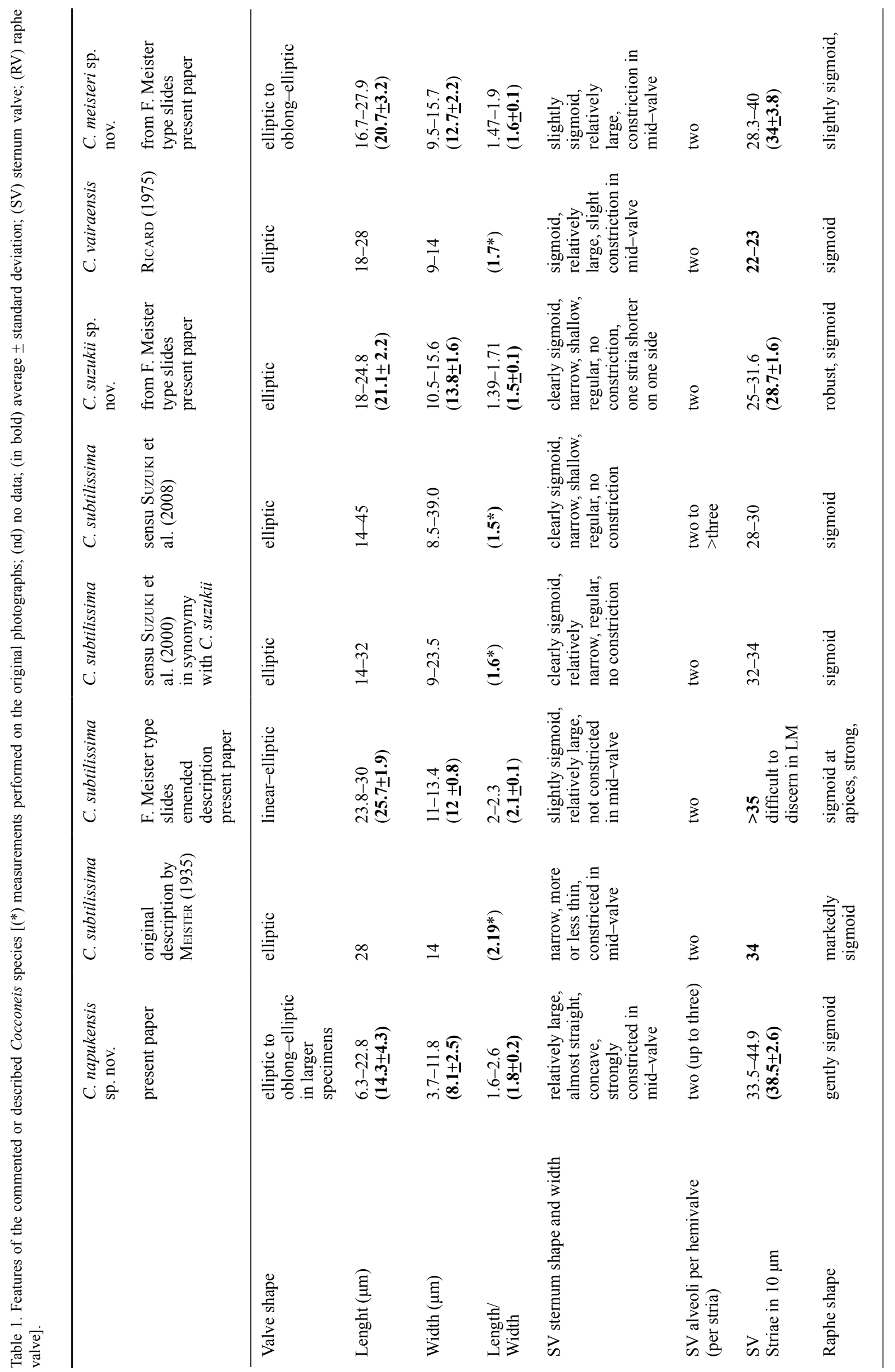




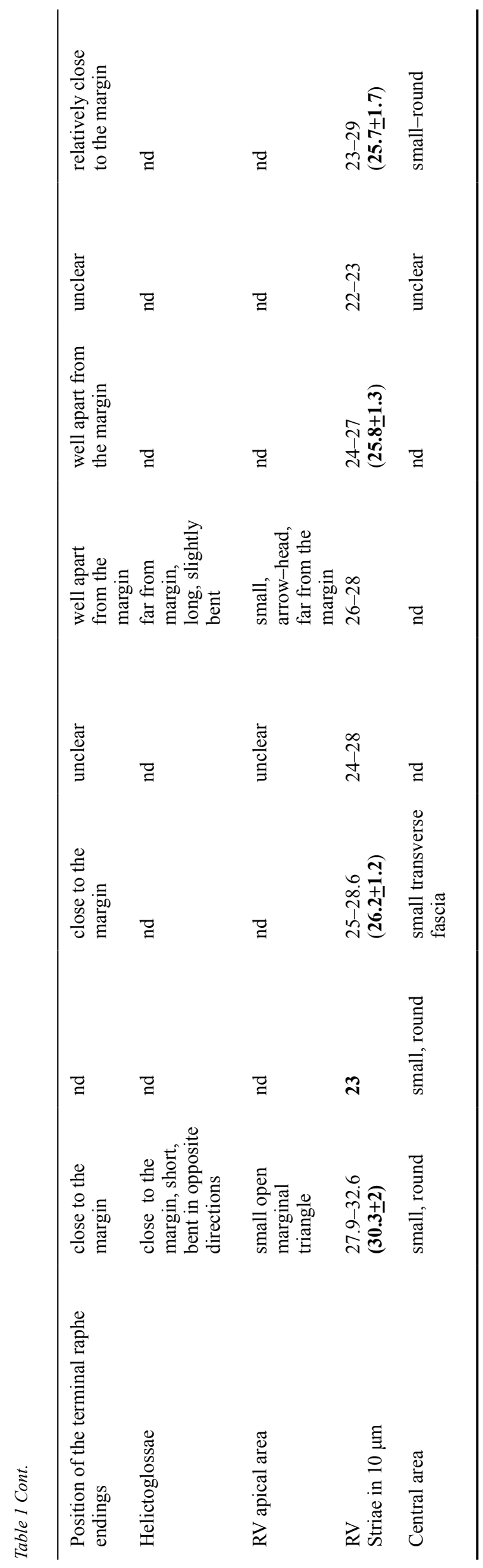

$\mathrm{L} / \mathrm{W}: 1.6 \pm 0.1$

Holotype: Permanent slide 'Nagasaki off shells 22046', from Voigt's slide collection housed in Dübendorf (Switzerland). Holotype specimen illustrated in Figs 21 (RV), 22 (SV).

Type locality: Nagasaki, Japan.

Etymology: Named in honor of Friedrich Meister.

Remarks: Cocconeis meisteri is not rare in the M. Voigt's slides. We first misidentified these specimens as C. subtilissima, due to the constriction of their SV sternum and referring to the German diagnose of the latter ('in der Schalenmitte enger'). Nevertheless, the valve shape and the RV features of $C$. meisteri differ completely from those of $C$. subtilissima.

Cocconeis suzukii RIAuX-GobIn et al. sp. nov. (LM, Figs 24-28, Table 1)

Synonym: Cocconeis subtilissima MeISTER sensu SUzUKI et al. [2000, figs 3 (RV), 4 (SV)].

Description: Valve elliptical with round apices, RV striae equidistant and radiate. Raphe robust, clearly sigmoid, terminal raphe fissures far from the margin and bent to opposite directions, central raphe endings robust, relatively close to each other. Axial area narrow, central area not expanded. SV striation easily discernible, each hemivalve carries a hyaline apically elongate area splitting the striae in two parts. Sternum large, elliptical and sigmoid, not constricted in midvalve, one mid-valve stria shorter on one side (Figs 26-27, arrows).

Morphometrics (LM, $\mathrm{n}=18)$ : $21.1 \pm 2.2 \mu \mathrm{m}$ long; $13.8 \pm 1.6 \mu \mathrm{m}$ wide

Stria densities: $28.7 \pm 1.6 \mathrm{SV}$ str. in $10 \mu \mathrm{m} ; 25.9 \pm 1.3 \mathrm{RV}$ str. in $10 \mu \mathrm{m}$

L/W: $1.5 \pm 0.1$

Holotype: F. Meister's type slide 'Nagasaki 3409001' housed in Herbarium of the University of Zürich. Holotype illustration: Figs 24 (RV), 25 (SV).

Holotype locality: Nagasaki, Japan (from the shell of a marine snail).

Etymology: This taxon is dedicated to Dr Hidekazu Suzuki who first illustrated it from a Japanese area.

Remarks: This taxon is not rare on F. Meister's and M. Voigt's slides. Its shape is rarely elongate, and the SV striation is coarser than in $C$. meisteri and $C$. subtilissima. Furthermore, the sigmoid SV sternum is different from that of $C$. meisteri. This taxon is similar to C. subtilissima MeISTer sensu SuzuKi et al. (2000). For this reason we propose the new species Cocconeis suzukii sp. nov. 

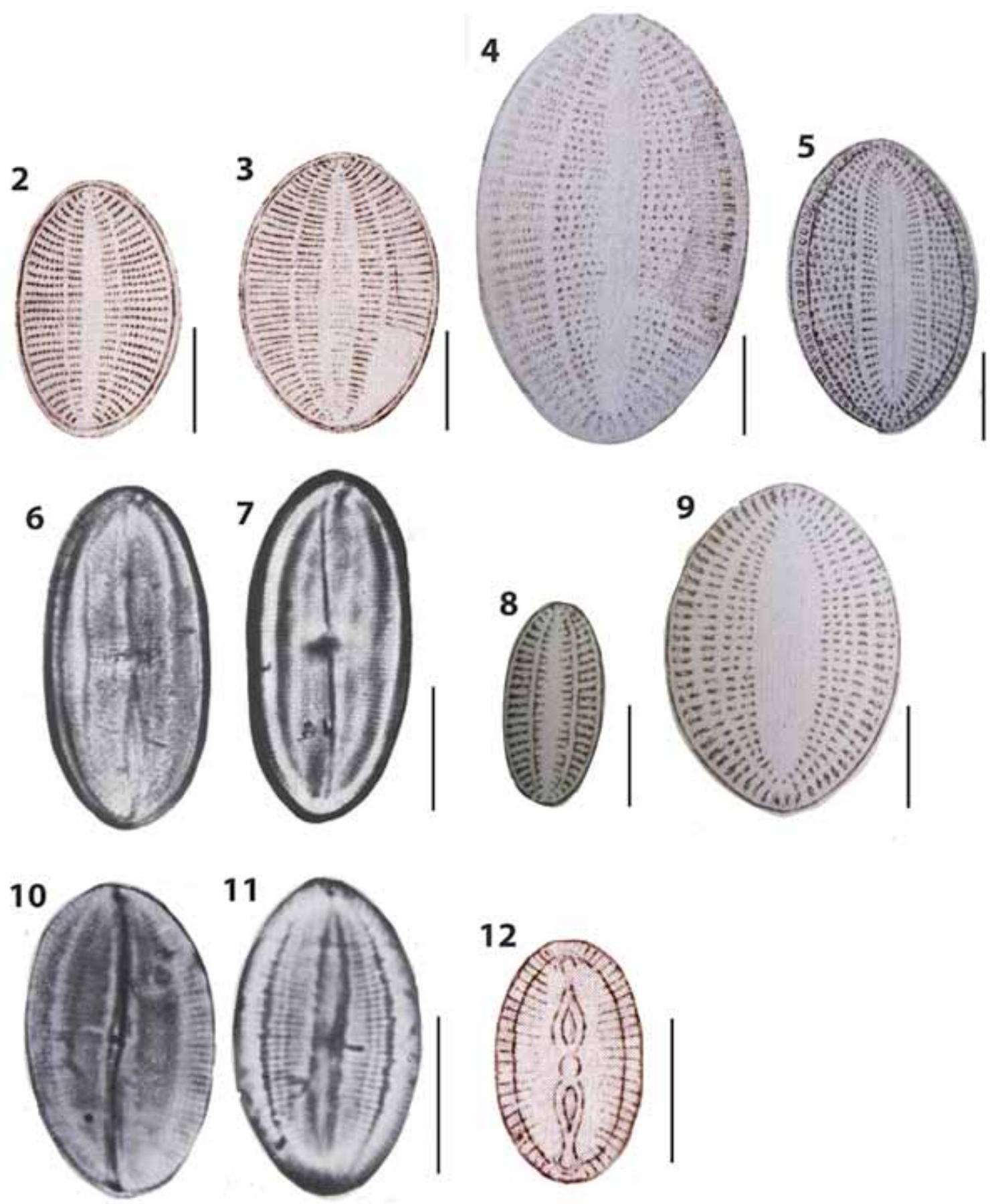

Figs 2-12: (2-5, 8-9) Cocconeis lorenziana Grunow 'formae minores', in Schмidt (reproduced from Schmidt 1894, pl. 191, figs 13-14, 24-27); (6-7) C. subtilissima MeISTer (reproduced from MeIster 1934, figs 61-62); (10-11) C. vairaensis RicARD (reproduced from RicARD 1975, pl. 2, fig. 21, with permission of the 'Publications scientifiques du Muséum national d'Histoire naturelle'); (12) C. comis A. SchмiDT (reproduced from SснміDт 1894, pl. 192, fig 2). Scale bars $10 \mu \mathrm{m}$.

\section{Material from Napuka Atoll (Tuamotu Archipelago, South Pacific Ocean)}

Cocconeis napukensis RIAUX-GoBIN et al. sp. nov. (LM, Figs 29-37; SEM, Figs 38-65; Table 1)

Description: Small-celled, elliptic to linear-elliptic with round apices (Figs 29-43).

Sternum valve (SV): Valve face externally strongly convex (Figs 38-41), bi-layered and strongly silicified, with two longitudinal rows of alveoli (up to three in larger specimens, i.e., Fig. 43), sternum almost straight to very slightly sigmoid, widely lanceolate, with no fascia, externally strongly constricted and concave in its mid-part (Figs 38-41). In the biggest specimens, the constricted part of the sternum may be a narrow straight band (Figs 40, 43). Striae uniseriate, dense, difficult to discern in LM (Figs 29-34). Alveoli regularly radiate, externally open by an oblong lumen interrupted by 

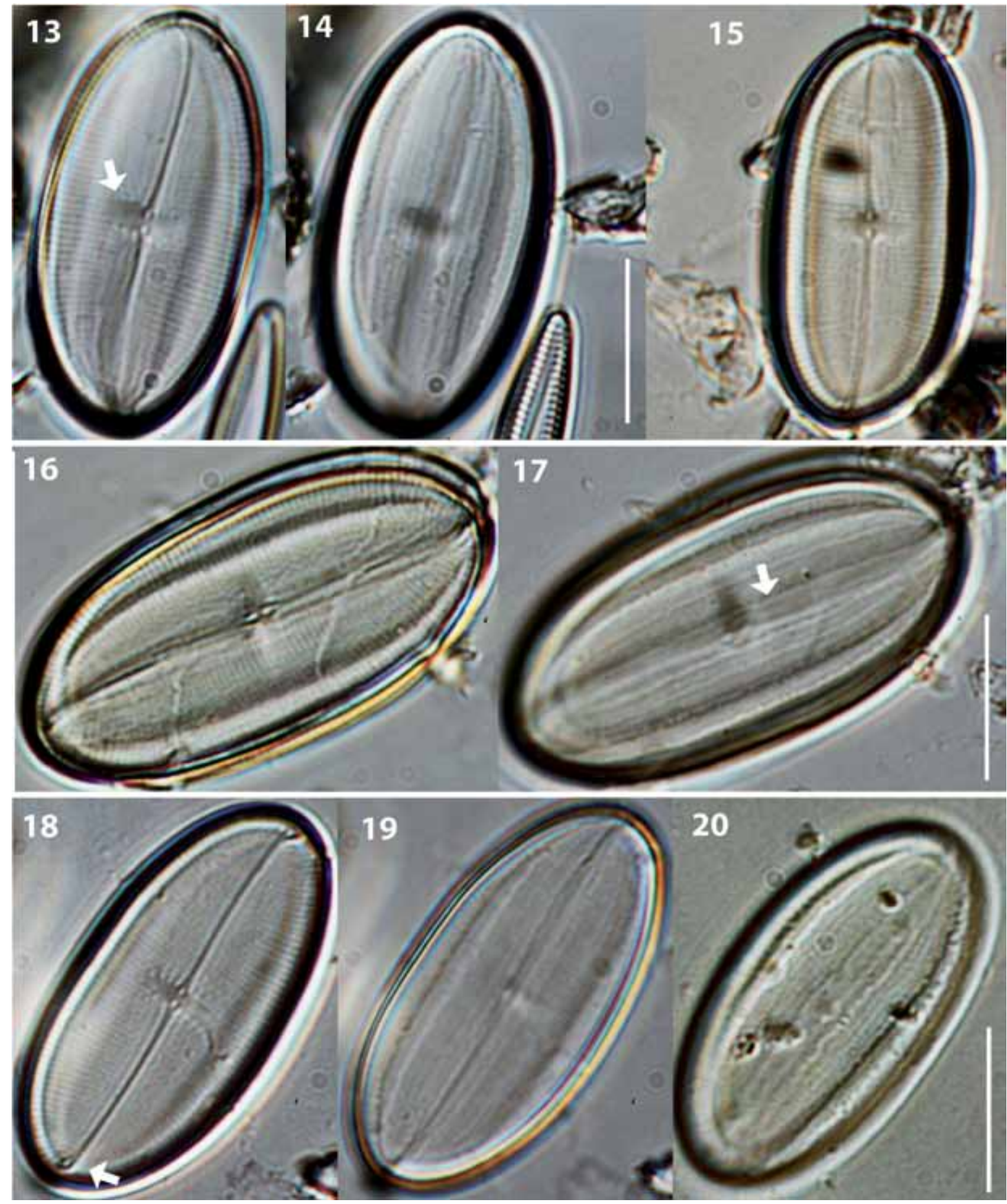

Figs 13-20. Cocconeis subtilissima MEISTER, from Nagasaki type material (LM): (13-14) Lectotype, complete valve at two different foci (raphe valve (RV) on the left, with a short fascia, arrow; sternum valve (SV) on the right); (15) RV alone; (16-17) complete valve at two different foci (RV on the left, SV on the right, showing the sternum with no apparent constriction); (18-19) complete valve at two different foci (RV on the left, with terminal raphe fissures strongly bent to opposite directions, arrow; SV on the right); (20) SV alone, showing the slightly sigmoid sternum. Scale bars $10 \mu \mathrm{m}$.

one (or two in the bigger specimens) hyaline and thin longitudinal line (Figs 41, 43, arrows). Apical alveoli short and deflected in opposite directions from one pole to the other. Internally, each alveolus opens to a small round pore, arranged along a regular apical line (Figs 44, 45, arrows). SV valvocopula (SVVC) robust (Fig. 48) and open (Fig. 49), with an irregular thin edge without fimbriae (Fig. 44, arrows; Fig. 49, arrow). The abvalvar (Fig. 49) and advalvar sides of the SVVC have no ornamentation (Fig. 43).

Raphe valve (RV): Externally flat to slightly concave. No fascia or marginal rim. Striae dense, uniseriate, regularly spaced and radiate (Figs 50-53), slightly denser close to apices. Central area reduced and round 

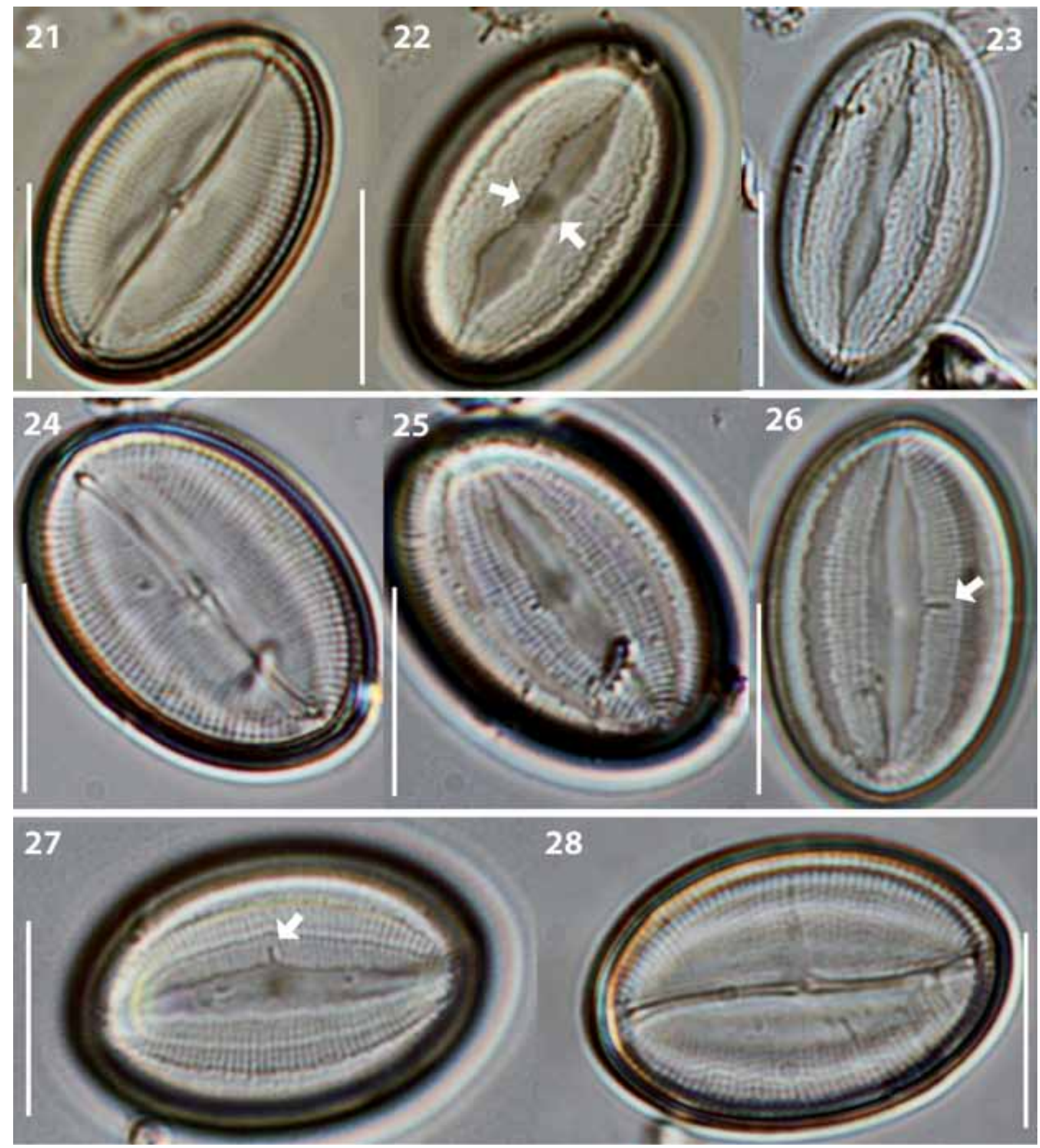

Figs 21-28. (21-23) Cocconeis meisteri sp. nov. from F. Meister slides (LM), (21-22) complete valve at two different foci (raphe valve (RV) on the left with a slightly sigmoid raphe, sternum valve (SV) on the right with a constricted sternum, arrows), (23) SV showing the hyaline areas on each hemivalve; (24-28) Cocconeis suzukii sp. nov. from F. Meister slides (LM), (24-25) illustration of the holotype (Type slide $\mathrm{n}^{\circ}$ 3409001), complete valve at two different foci (RV on the left with a strong raphe and terminal raphe fissures far from the margin; SV on the right with a sigmoid large sternum, with one stria shorter, arrow), (26) SV with a sigmoid sternum, with one stria shorter on one side, arrow, (27-28) complete valve at two different foci (RV on the right with a strong sigmoid raphe; SV on the left with a sigmoid large sternum, with one stria shorter, arrow). Scale bars $10 \mu \mathrm{m}$.

(Fig. 50). Areolae small, round and regular, occluded by depressed hymenes, with marginally and radially arranged short slits (Fig. 54). One marginal row of areolae occasionally slightly oblong. Small apical area devoid of areolae (Fig. 50, arrow). Axial area narrow. Raphe filiform, slightly sigmoid, with proximal raphe endings close to each other and distal raphe fissures simple and close to the margin (Figs 50, 51, 53).
Internally, the raphe is bordered by slightly raised ribs (Fig. 55). Helictoglossae short, raised and curved in opposite directions (Figs 56, arrow; 57). Complex and high cingulum composed of the two open valvocopulae and several additional open connecting bands (Figs 60-65). RV valvocopula (RVVC) thick, open, with the advalvar edge slightly crenelated (Fig. 58, short white arrows; 63, white arrow). 

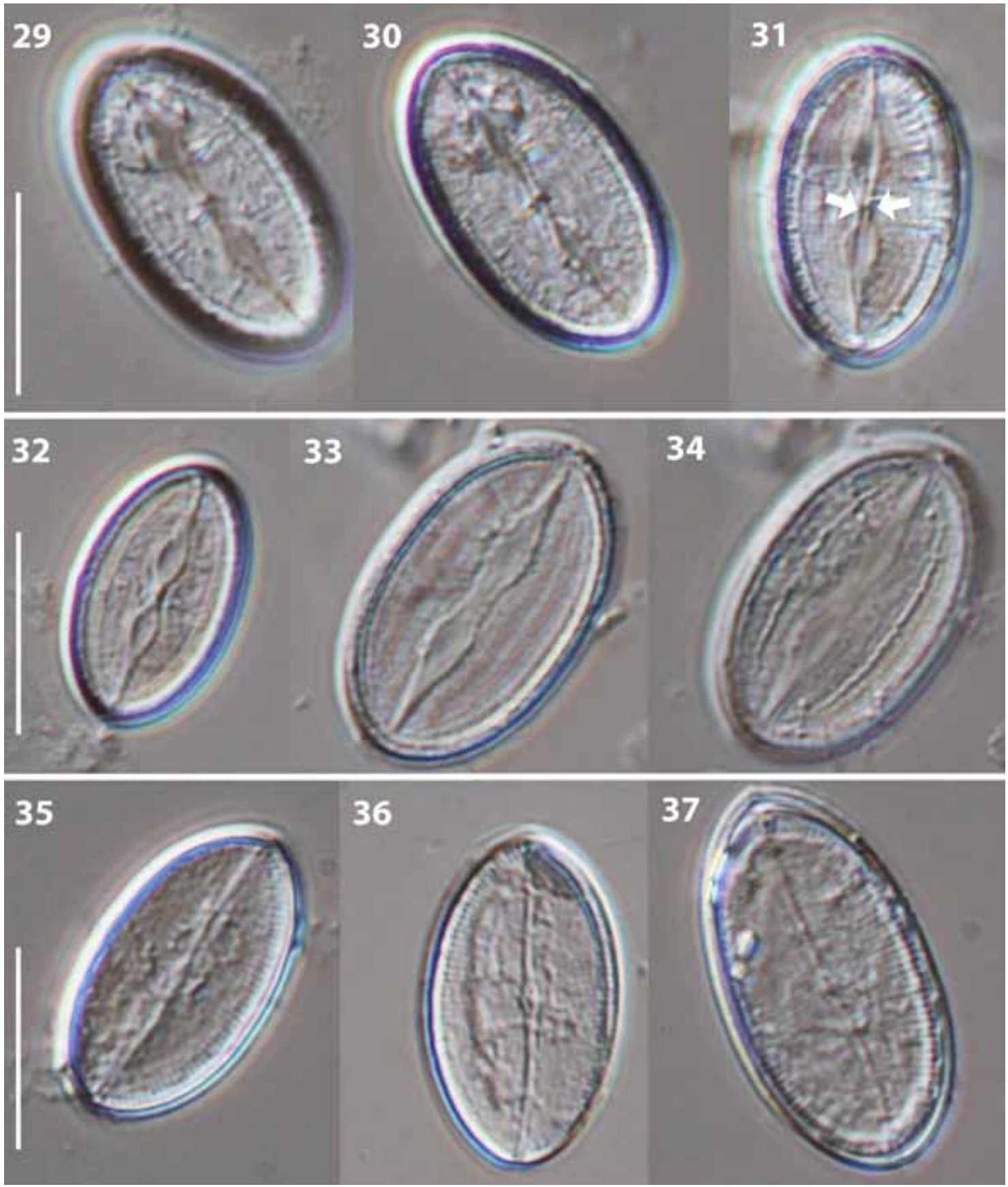

Figs 29-37. Cocconeis napukensis sp. nov. from Napuka (LM): (29-30) complete valve at two different foci (sternum valve (SV) on the left, raphe valve (RV) on the right); (31) complete valve showing the central raphe endings and the constricted sternum (arrows); (32) SV showing the constricted sternum; (33-34) SV at two different foci showing the hyaline axial area on each hemivalve; (35-37) RV views, with stria pattern. Scale bars $10 \mu \mathrm{m}$.

Morphometrics $(\mathrm{n}=50): 6.3-22.8 \quad(14.3 \pm 4.3) \mu \mathrm{m}$ long; 3.7-11.8 (8+2.5) $\mu \mathrm{m}$ wide

Stria densities: $33.5-44.9(39.4 \pm 2.6)$ SV str. in $10 \mu \mathrm{m}$; 27.9-32.6 (30.3 \pm 2$) \mathrm{RV}$ str. in $10 \mu \mathrm{m}$

L/W: $1.8 \pm 0.2$

Holotype: SEM stub no. 1 15NPK 7-2 12/07/2013 stored in C. Riaux-Gobin collection at CRIOBEUniversité de Perpignan, France, Holotype specimen illustrated in Fig. 43.
Isotypes: from sample $15 \mathrm{NPK} 7-2$, sampled in 25 september 2012, slide BM101713 deposited in the Natural History Museum (London, UK) and slide NPK1 in collection C. Riaux-Gobin.

Type locality: Napuka marine coastal environment, Tuamotu ( $\left.14^{\circ} 10.702 \mathrm{~S} ; 141^{\circ} 15.949 \mathrm{~W}\right)$. Collected by C. Riaux-Gobin, 25 September 2012.

Habitat: Until now only found on Napuka Atoll (Tuamotu).

Etymology: The epithet refers to Napuka Atoll where 

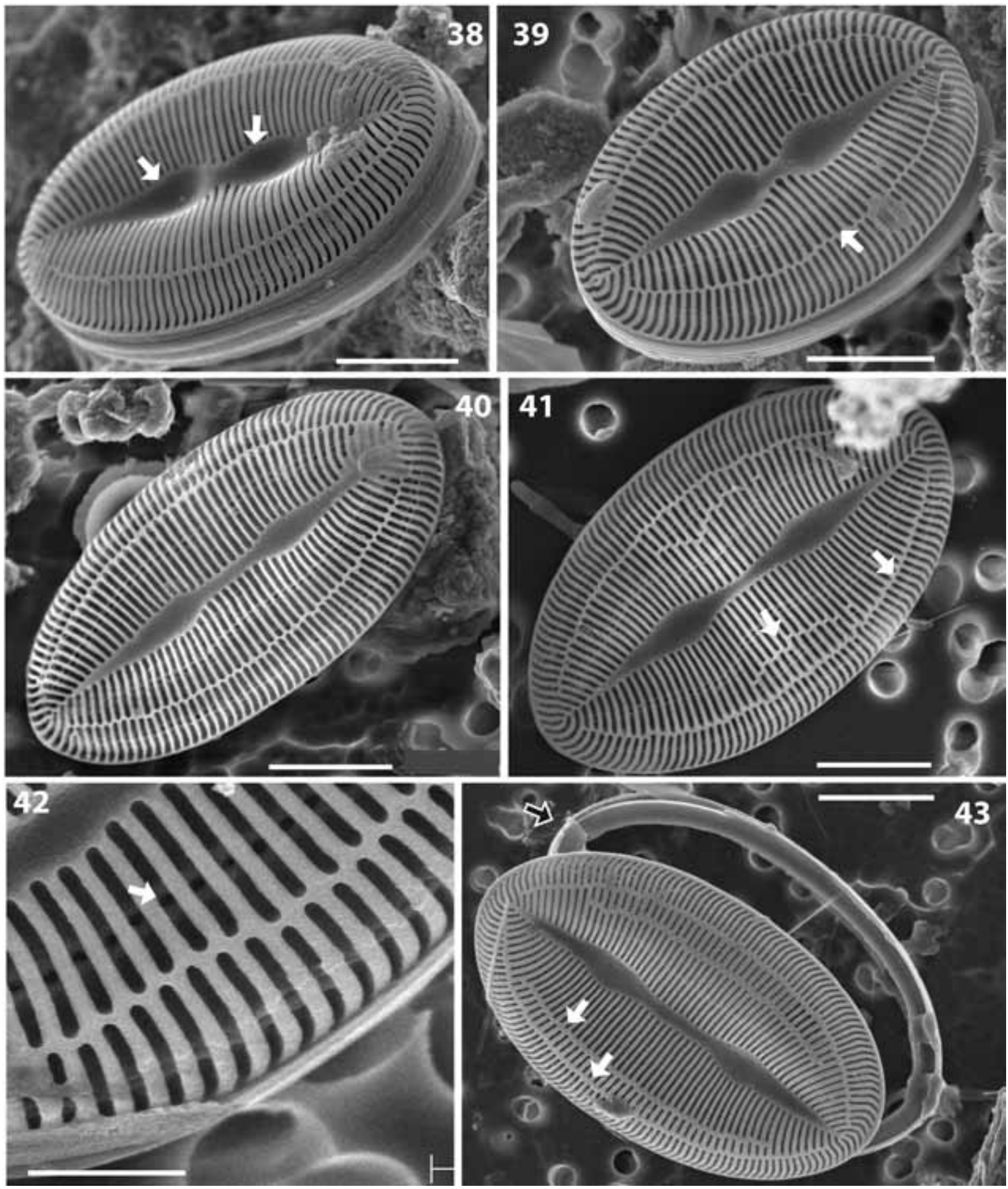

Figs 38-43. Cocconeis napukensis sp. nov. from Napuka (SEM). External views of the sternum valve (SV): (38) cingular view, note the two strongly concave constricted parts of the sternum (arrows); $(39,40)$ specimens with two alveoli. The arrow show the thin hyaline area externally delineating the alveoli; $(41,43)$ Holotype, larger specimens with three alveoli and two hyaline areas (arrows); sternum valve valvocopula (SVVC) open (Fig. 43, framed arrow) with smooth edge; (42) focus on the lumen of the alveoli, with a row of pores giving access to the interior of the cell (arrow). Scale bars $4 \mu \mathrm{m}$ (29); $3 \mu \mathrm{m}$ (24-27);1 $\mu \mathrm{m}$ (28).

the species was discovered.

Remarks: Cocconeis napukensis SV has some similarities with the SV illustrated in SснміDт (1894) pl. 196, fig 8 (specimen on the right) under Cocconeis vetusta A. Sснмidt. But the illustrated RV of the latter (left specimen in fig. 8, ref. cit.) has a transverse hyaline fascia much larger than in C. napukensis. Also some similarities with the SV illustrated in SCHMIDT (1894) pl. 192, fig 2 (reproduced in our Fig. 12), under Cocconeis comis A. SCHMid, but with a striation less dense than that in C. napukensis. C. comis $\mathrm{RV}$ 

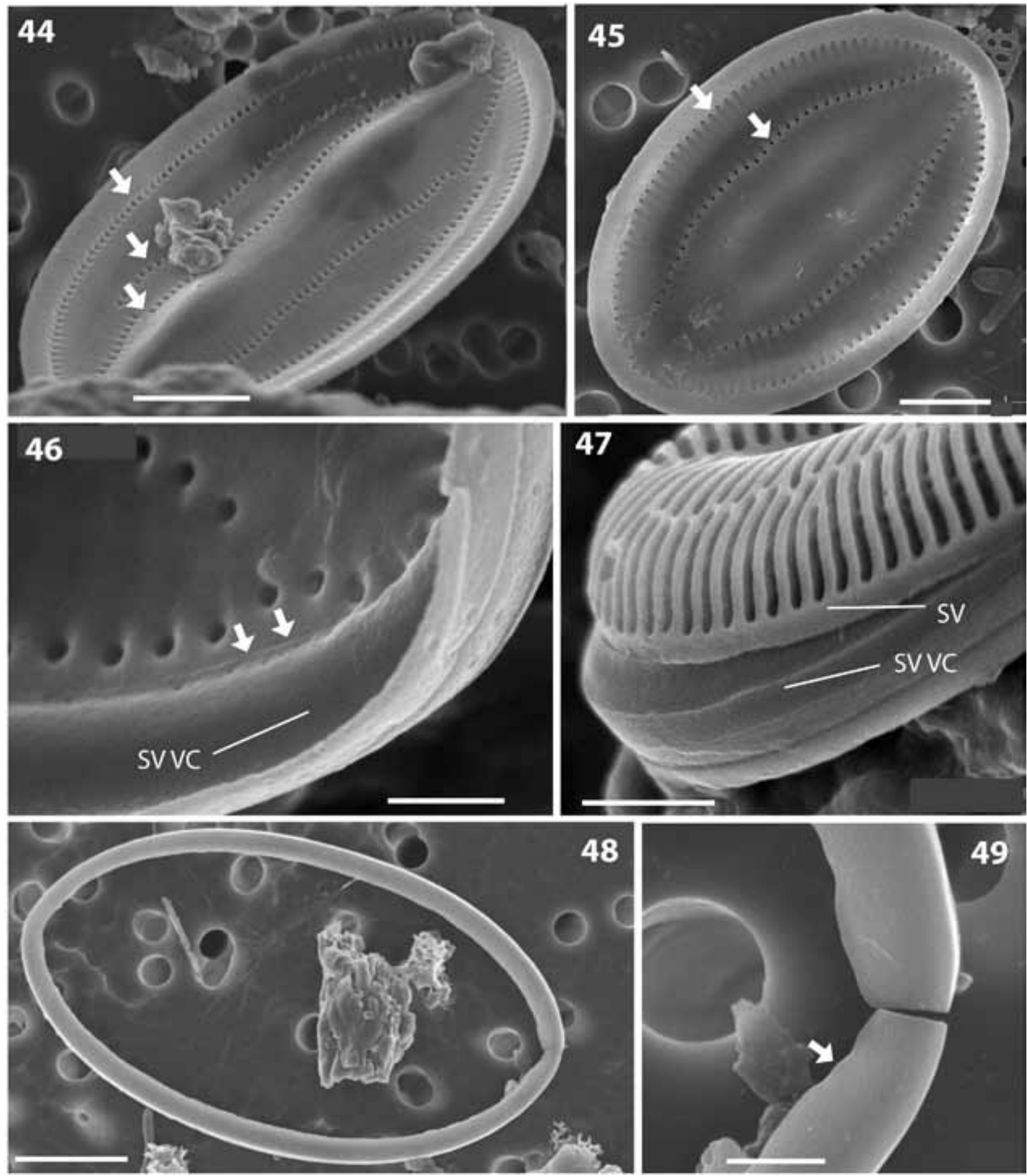

Figs 44-49. Cocconeis napukensis sp. nov. from Napuka (SEM). Internal views and details of the sternum valve (SV): $(44,45)$ rows of pore, regularly arranged, giving access to the cell (arrows); (46) detail of the abvalvar side of the sternum valve valvocopula (SVVC) with thin edge without fimbriae (arrows); (47) cingular view showing the SV and SVVC slightly disconnected; $(48,49)$ open SVVC in abvalvar side showing the irregular margin (arrow). Scale bars $3 \mu \mathrm{m}$ (44, 48); $2 \mu \mathrm{m}$ (45); $1 \mu \mathrm{m}$ (47); $600 \mathrm{~nm}$ (49); $500 \mathrm{~nm}$ (46).

is not illustrated and not enough characteristics are mentioned for this taxon to permit a comparison with C. napukensis. Cocconeis lorenziana GRUNow 'formae minores', in Sснмidт (1894) pl. 191, figs 13-14, 24-27 (reproduced in our Figs 2-5, 8-9), illustrated by SEM in Montgomery (1978, pl. 68, figs E, F), has some similarities with our taxon: i.e., presence of two rows of alveoli. But the valve of the latter is less elongate than in C. napukensis, and the SV sternum, even if irregular, is not constricted. Furthermore, the specimens of $C$. lorenziana GRUNOw 'formae minores' illustrated in ScнмiDt (ref.cit.) have a lower SV stria density than C. napukensis. It can be remarked that the SEM illustrations by MONTGOMERY (ref. cit.) somehow fit the illustrations of $C$. subtilissima MeIster sensu Suzuki et al. 2000, here described as Cocconeis suzukii. Several features differentiate $C$. napukensis from C. subtilissima Meister sensu Suzuki et al. 

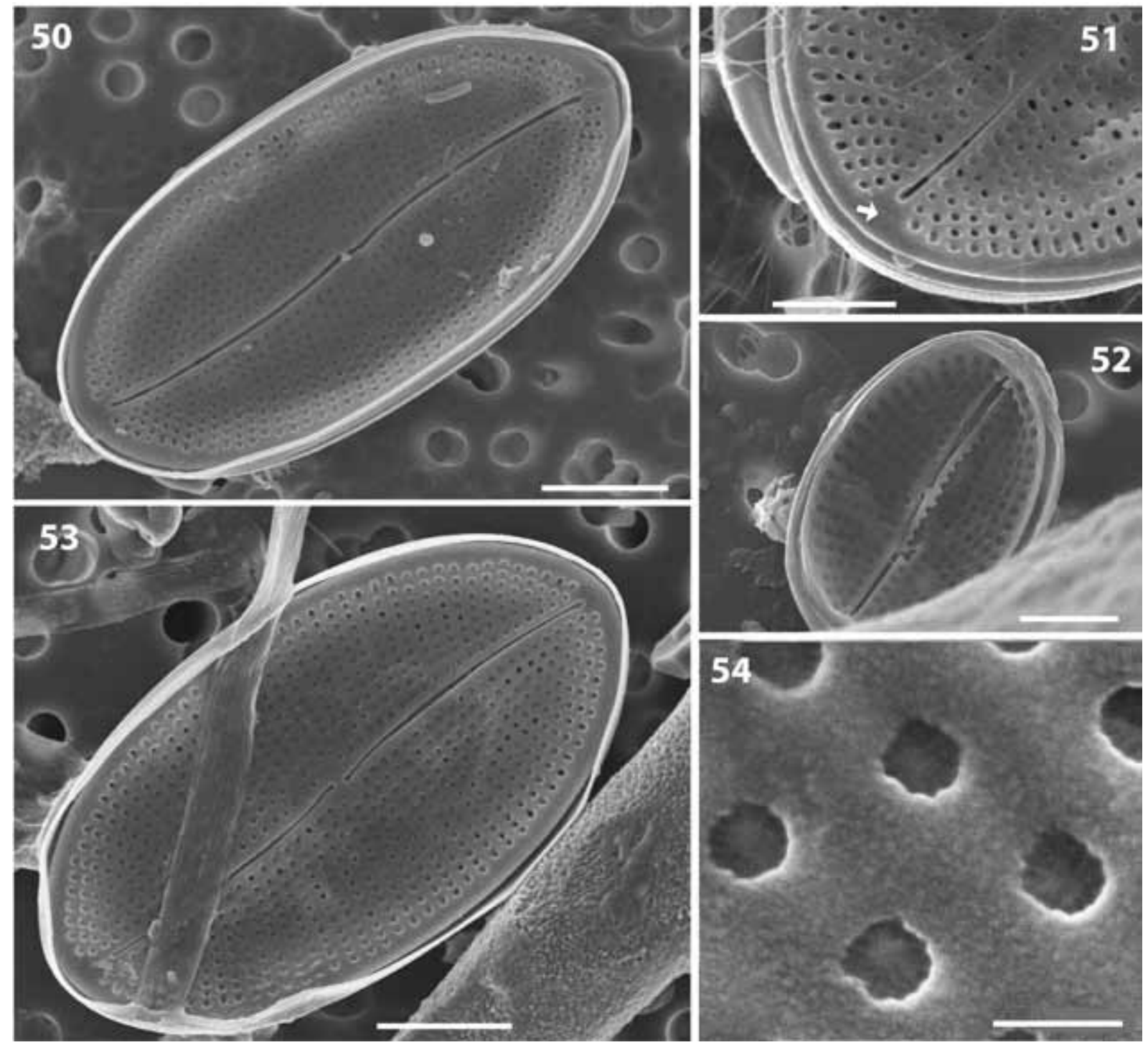

Figs 50-54. Cocconeis napukensis sp. nov. from Napuka (SEM). External views of the raphe valve (RV): $(50,52,53)$ RV of different sizes, almost plane, with a slightly sigmoid raphe, regularly spaced and radial striae and narrow axial area; (51) detail showing the apical triangular area devoid of areolae and terminal raphe ending close to the margin; (54) detail of the areolae with hymenes showing short marginal slits. Scale bars $3 \mu \mathrm{m}(50,53) ; 2 \mu \mathrm{m}(51,52) ; 200 \mathrm{~nm}(54)$.

2000, here described as Cocconeis suzukii (see above, Discussion and Table 1): 1) a smaller length (on average $14.3 \mu \mathrm{m}$ long versus 21.1 , Table 1), 2) a different outline of the valve (oblong-elliptical to linearelliptical in C.napukensis), 3) the SV sternum pattern, strongly constricted and straight in C. napukensis, while clearly sigmoid in Cocconeis suzukii, 4) if the $\mathrm{RV}$ is relatively similar on both taxa, the raphe terminal fissures in C. napukensis are close to the margin with valve apices completely free of areolae (Figs 50, 51, 53), while in Cocconeis suzukii they are far from the margin with some areolae present along the margin delineating a small arrow-head area devoid of areolae, 5) the helictoglossae are short and abruptly deflected in opposite directions in C. napukensis (Fig. 56), while long and sigmoid in Cocconeis suzukii (see $C$. subtilissima sensu SuzuKI et al. 2008, fig. 19, arrow),
6) the hyaline line externally delineating each alveolus is thin and regular in C. napukensis (Fig. 40-43) while larger in Cocconeis suzukii.

C. napukensis also has some similarities with Cocconeis meisteri sp. nov. found in the material of Meister (Figs 21-23), but with 1) smaller dimensions, 2) a more elongated shape (L/W 1.8 versus 1.6, Table 1), 3) three alveoli per stria on the bigger specimens versus two for $C$. meisteri, 4) stria densities higher on both valves, and 5) a more pronounced constriction of the SV sternum.

Cocconeis vairaensis RICARD (1975, pl. 2, fig. 21, reproduced in our Figs 10-11) (type slide and raw material not localized) has also some likeness with our new taxon, but is less elongate, has less dense striation and a same stria density on both valves $(22-23 \mathrm{str}$. in $10 \mu \mathrm{m}$, Table 1), its SV sternum is irregular and only 


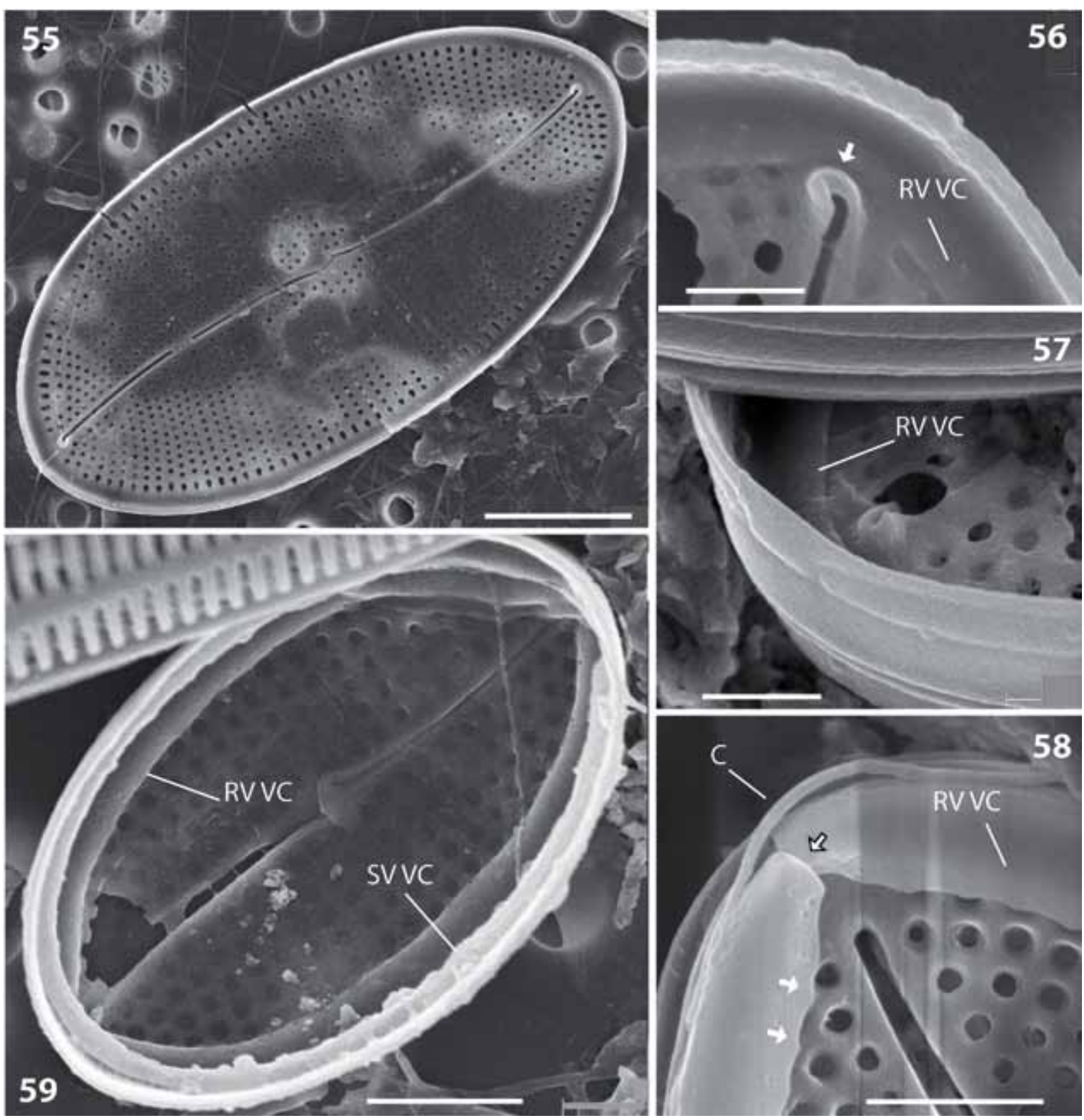

Figs 55-59. Cocconeis napukensis sp. nov. from Napuka (SEM). Internal views of the raphe valve (RV): (55) RV showing the small-sized central area and the slightly sigmoid raphe; (56) apex of the RV with the short helictoglossa abruptly bent (arrow) and the raphe valve valvocopula (RVVC) in abvalvar side; (57) cingular view showing the same details as in Fig. 56; (58) RV with the two valvocopulae still attached; (59) apex with the open (framed arrow) RVVC in advalvar side, with short indentations (white arrows). A copula is indicated (C). Scale bars $4 \mu \mathrm{m}(55) ; 2 \mu \mathrm{m}$ (58); $1 \mu \mathrm{m}(59) ; 700 \mathrm{~nm}(57) ; 600 \mathrm{~nm}$ (56).

very slightly constricted in the middle, and its RV is more deeply sigmoid than that of C. napukensis.

Finally, C. napukensis can be compared to $C$. subtilissima MeIster (see above emended description). The two taxa differ by their shape (more oblonglineal and with blunt apices in $C$. subtilissima), by their RV stria pattern (presence of a short fascia in $C$. subtilissima), and by their SV pattern (no constriction of the SV sternum in C. subtilissima).

It can be remarked that $C$. subtilissima and $C$. napukensis concurrently possess a significantly denser striation on their SV, contrarily to $C$. suzukii and to $C$. vairaensis (Table 1).

\section{Discussion}

First discovered by Meister (1935) from a Japanese marine sample, $C$. subtilissima has been diversely interpreted by subsequent authors (i.e., SuzUKI et al. 2000; De Stefano \& Romero 2005; Suzuki et al. 2008; RiauX-Gobin et al. 2011; MajewsKa et al. 2013) entangling its real identity. But, following the original description and our examination of the type material, and except for some remarks by F. Meister that were erroneous (i.e, concerning the central area of the RV that is in fact a short fascia, and the SV sternum that is 

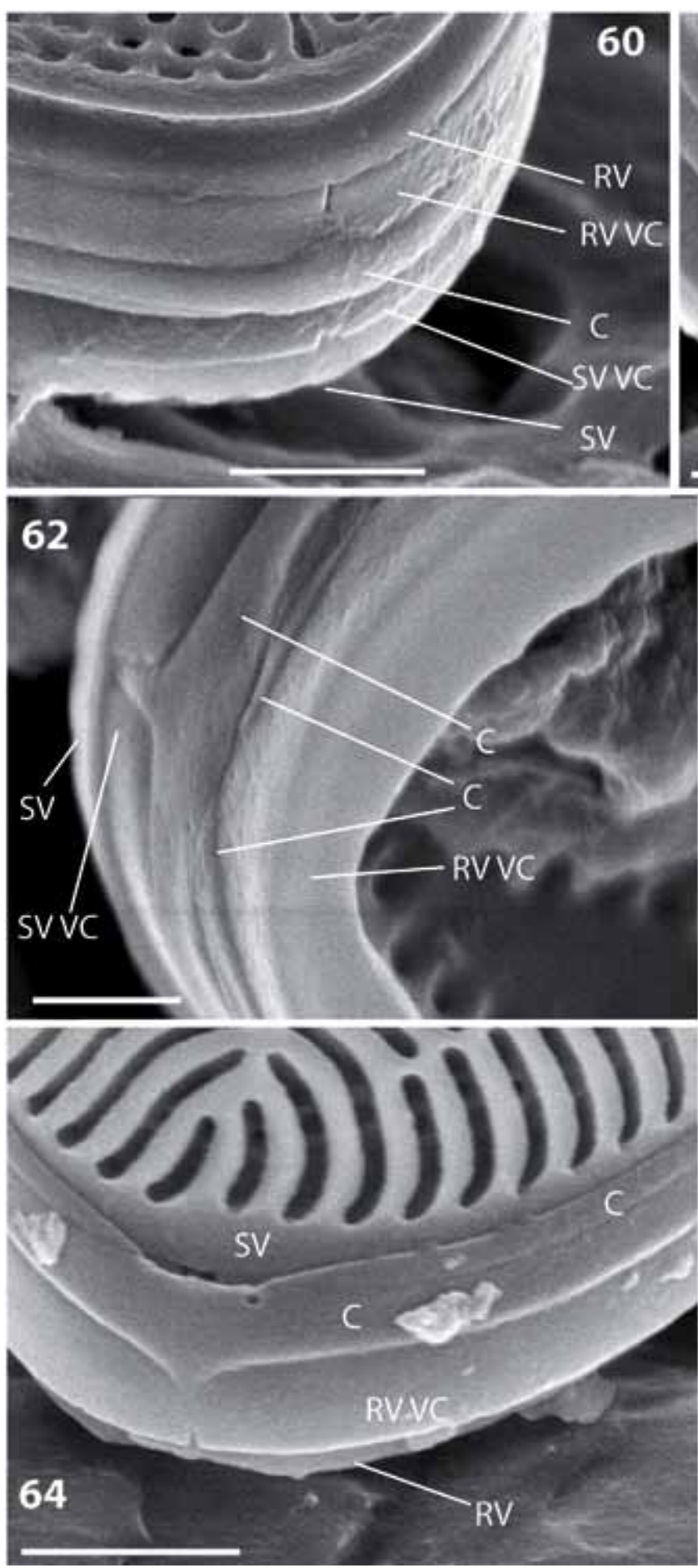

Figs 60-65. Cocconeis napukensis sp. nov. from Napuka (SEM). Detail of the cingular bands. The high and complex cingulum is composed of the two open valvocopulae (raphe valve valvocopula (RVVC) and sternum valve valvocopula (SVVC), two open copulae (C) and the mantle of each valve (VC, RV). $(62,63)$ particularly show the open RVVC in place (framed arrow, Fig. 63) and crenulated edge of the RVVC in advalvar side (white arrow, Fig. 63). Scale bars $1 \mu \mathrm{m}(60,61,63,64) ; 500 \mathrm{~nm}(62,65)$.

not constricted), all other points fit exactly and the later interpretations were wrong.

In fact, De Stefano \& Romero (2005, pls 32-33), Suzuki et al. (2008, figs 1-44), Riaux-Gobin et al. (2011, pl. 6/3-11, pls 73, 74) and MAJEwSKA et al. $(2014$, fig. 2, 31) roughly follow the definition by SuzuKi et al. (2000). It can be noted that none of the
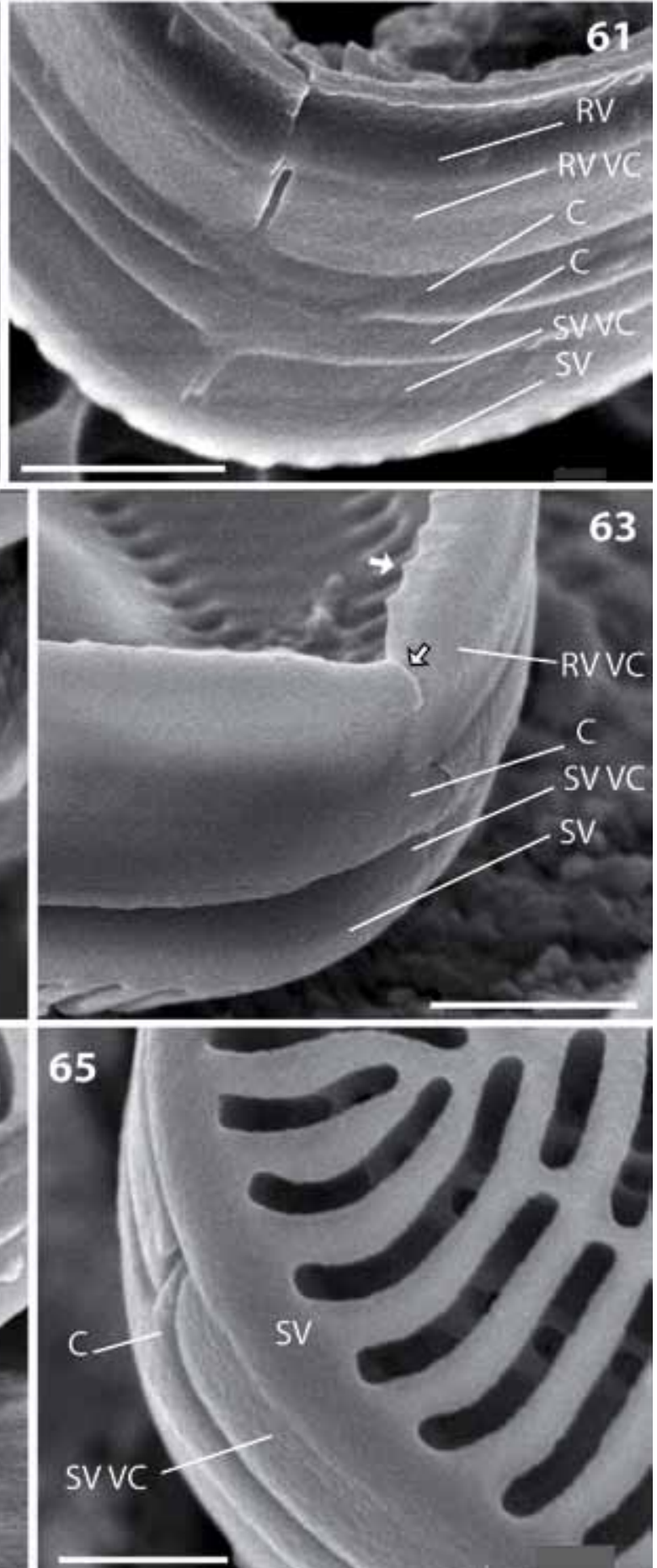
26 , with wrong scale bars: $-10 \mu \mathrm{m}$ instead of $5 \mu \mathrm{m}-$ ) while the rest of the description somehow differs from the first description by SuzUKI et al. (2000) (see Table 1), i.e., the valves illustrated in SuzUKI et al. (2008) are in major part largely elliptical and not oblong and the stria densities are significantly different. The SEM illustration in MAJEwsKa et al. (2013, fig. 2,31) is the exact reproduction of fig. 1, pl. 32 of De Stefano \& Romero (2005) and not an illustration of their Mediterranean material.

In conclusion, Cocconeis subtilissima MEISTER differs from Cocconeis subtilissima sensu SuzUKI et al. (2000), and it is the reason why we propose to define the new species Cocconeis suzukii sp. nov. All the taxa discussed in the present paper, including Cocconeis napukensis sp. nov., Cocconeis meisteri sp. nov. and Cocconeis vairaensis, differ from each other by several of their features (see Table 1 and key). These smallcelled marine Cocconeis probably belong to the same group of species. Genetic data would be useful to show their taxonomic relationship.

The rich diversity of benthic diatoms from tropical and coral reef samples are up till now poorly documented (see introduction). Several new Achnanthales species and a new genus were recently described from the South Pacific (RIAUX-Gobin et al. 2013, 2014a), while numerous other taxa are in common with the flora described from the Indian Ocean (i.e., Mascarenes, RIAUX-GoBIN et al. 2011). On the other hand, it is always time-consuming to explore the type collections (when they are found) but it is the only way to get a reliable concept of a taxon. In the case of $C$. subtilissima, the original photographs gave a good description that was later wrongly interpreted. In the same way, some reference books may give haphazard information if types are not checked (i.e., concerning Cocconeis pinnata GREGORY and C. ornata Gregory in Hustedt 1931-1959, Riaux-Gobin et al. $2014 \mathrm{~b}, \mathrm{c})$ that can induce subsequent misidentification.

\section{Key to discriminate the discussed taxa}

1. Elongated frustule, $\mathrm{L} / \mathrm{W}>2$, SV sternum almost straight, not constricted at mid-valve, short fascia on the RV ..............

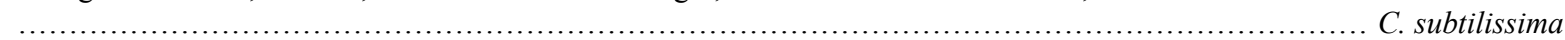

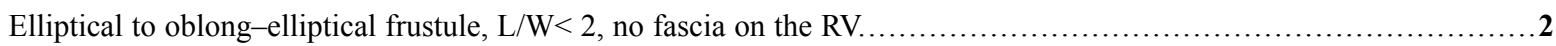

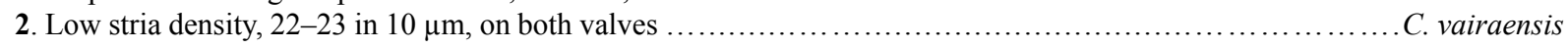

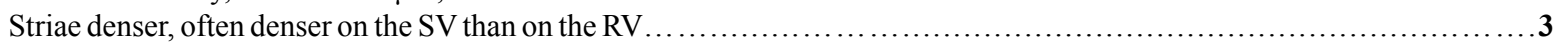

3. SV sternum not constricted at mid-valve, terminal raphe endings well apart from the margin............................... SV sternum constricted at mid-valve, terminal raphe endings close to the margin or unclear, high SV stria

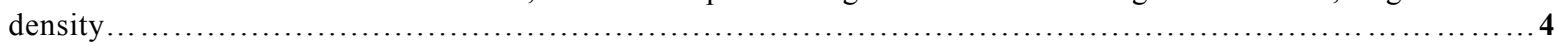

4. Av. $34 \mathrm{SV}$ striae in $10 \mu \mathrm{m}$, av. $26 \mathrm{RV}$ striae, SV sternum slightly sigmoid, not strongly constricted at mid-valve, L/W $1.6 \ldots \ldots$ C. meisteri

Smaller size, striae slightly denser on both valves, SV almost straight, strongly constricted at mid-valve, L/W $1.8 \ldots \ldots$

\section{ACKNOWLEDGMenTs}

Jean Kape 'Fasan Chong', Remy Tchong and Marina Taki are warmly acknowledged for their hospitality and friendship during the stay of C. R.-G. in Napuka Atoll. René Galzin (CRIOBE-Moorea, French Polynesia) greatly helped in the logistic of the project. Thanks are also due to Oscar E. Romero (MARUM-Center for Marine Environmental Sciences, University of Bremen). We warmly acknowledge the anonymous reviewers and Aloisie Poulíčková for improving the manuscript, and Friedel Hinz (BRM) and Regula Illi (M. Voigt Collection Curator, Eawag, Dübendorf, Schweiz) for the loan of original material, Dimitri Gorand (C2M, Perpignan University) for his assistance with the SEM and Margie Koster, Switzerland, for the English revision. Naturalia \& Biologia and CNRS-USR 3278 funded the CORDIA 2012 project.

\section{REFERENCES}

ANONYMous (1975): Proposals for a standardization of diatom terminology and diagnoses. - Nova Hedwigia Beih. 53: $323-354$.

Charpy, L. (2001): Phosphorus supply for atoll biological productivity. - Coral reefs 20: 357-360.

Cibois, A. \& Thibault, J.-C. (2005): Les oiseaux de Napuka (Nord Tuamotu). - Te Manu 50.
Charpy-Roubaud, C.J.; Charpy, L. \& Cremoux, J.-L. (1990): Nutrient budget of the lagoonal waters in an open South Pacific atoll (Tikehau Tuamotu French Polynesia). - Mar. Biol. 107: 67-73.

De Stefano, M. \& Romero, O.E. (2005): A survey of alveolate species of the diatom genus Cocconeis (Ehr.) with remarks on the new section Alveolatae. Bibl. Diatomol. 52: 133.

Hatcher, B.G. (1997): Organic production and decomposition. - In: Birkeland, C. (ed.): Life and Death of Coral Reefs. - pp. 230-248, Chapman and Hall, New York.

Hustedt, F. (1931-1959): Die Kieselalgen Deutschlands, Österreichs und der Schweiz unter Berücksichtigung der übrigen Länder Europas sowie der angrenzenden Meeresgebiete. -In: Rabenhorst, L. (ed): 2. Teil. - Kryptogamen-Flora von Deutschland, Österreich und der Schweiz. Band 7, Teil 2. - 845 pp., Akademische Verlagsesellschaft, Leipzig.

Krasnick, G.J. (1973): Phytoplankton pigments and nutrients concentrations in Fanning lagoon. Fanning hi. Exped. Julyaugust 1972, Final Rep. - Hawaii Inst. Geophys., HIG-72-13: 51-60, 1 fig.

LeClerc, A.-M. (1998): Modélisation des écoulements dans 
le milieu interstitiel corallien et quantification des échanges de matière avec l'environnement océanique [Thèse Doctorat]. - 199 pp., Ecole Nationale Supérieure des Mines de Paris.

Magnier, Y. \& Wauthy, B. (1976): Esquisse hydrologique du lagon de Takapoto (Tuamotu). - Cah. ORSTOM, sér. Océanogr. 14: 279-287.

Marshall, N. (1965): Detritus over the reef and its potential contribution to adjacent waters of Enewetak atoll. Ecology 46: 343-344.

Majewska, R.; D’Alelio, D. \& De Stefano, M. (2013): Cocconeis Ehrenberg (Bacillariophyta), a genus dominating diatom communities associated with Posidonia oceanica Delile (monocotyledons) in the Mediterranean Sea. - Aquat. Bot. 112: 48-56.

McNeill, J.; Barrie, F.R.; Buck, W.R.; Demoulin, V.; Greuter, W.; Hawksworth, D.L.; Herendeen, P.S.; Knapp, S.; Marhold, K.; Prado, J.; Prud'homme van Reine, W.F.; Smith, G.F.; Wiersema, J.H. \& Turland, N. (Eds. \& Comps.) (2012): International Code of Nomenclature for algae, fungi, and plants (Melbourne Code), adopted by the Eighteenth International Botanical Congress Melbourne, Australia, July 2011. - 208 pp., Koeltz Scientific Books, Königstein.

Meister, F. (1935): Seltene und neue Kieselalgen. - Ber. Schweiz. bot. Ges. 44: 87-108.

Montgomery, R.T. (1978): Environmental and ecological studies of the diatom communities associated with the coral reefs of the Florida Keys, vols I \& II. [Ph.D. thesis,]. - 336 pp., 204 pls, Florida State University, Tallahassee, FL.

RiauX-Gobin, C.; Compère, P. \& Ector, L. (2014a): Some Cocconeis species (Bacillariophyceae) originally described by William Gregory and Robert Kaye Greville from the Firth of Clyde and Loch Fyne (Scotland). - Nova Hedwigia 99: 171-192, DOI: 10.1127/0029-5035/2014/0190

Riaux-Gobin, C.; Compère, P.; Romero, O.E. \& Williams, D.M. (2014b): Cocconeis pinnata W. GREGORY ex GREVILle (Bacillariophyta): lectotypification and an emended description after examination of type material and South Pacific specimens. Phytotaxa 156: 81-99, http://dx.doi.org/10.11646/ phytotaxa.156.3.1

Riaux-Gobin, C.; Coste, M.; Jordan, R.W.; Romero, O.E. \& Le CoHU, R. (2014c): Xenococconeis opunohusiensis gen. et sp. nov. and X. neocaledonica comb. nov. (Bacillariophyta) from the tropical South Pacific. - Phycol. Res., DOI: 10.1111/pre.12046

Riaux-Gobin, C.; Romero, O.; Compère, P. \& AlHAndal, A. (2011): Small-sized Achnanthales (Bacillariophyta) from coral sands off Mascarenes (Western Indian Ocean). - Bibl. Diatomol. 57: $1-234$.

Riaux-Gobin, C.; Romero, O.E.; Coste, M. \& Galzin, R. (2013): A new Cocconeis (Bacillariophyceae) from Moorea Island, Society Archipelago, South Pacific Ocean with distinctive valvocopula morphology and linking system. - Bot. Mar. 56: 339-356.

Riaux-Gobin, C.; Compère, P. \& Jordan, R.W. (submitted): Cocconeis Ehrenberg assemblage (Bacillariophyceae) at Napuka Atoll (Tuamotu Archipelago, South Pacific) with description of several new taxa. - Diatom Res.
RicARD, M. (1975): Quelques diatomées nouvelles de Tahiti décrites en microscopie photonique et électronique à balayage. - Bull. Mus. Natl. Hist. Nat. 3 326: 201230.

Ricard, M.; Gueredrat, J.A.; Magnier, Y.; Renon, J.P.; Rochette, J.P.; Rougerie, F.; Sournia, A. \& Wauthy, B. (1979): Le plancton de Takapoto. - J. Soc. Océanistes 35: 47-67.

Ross, R.; Cox, E.J.; Karayeva N.I.; Mann, D.G.; Paddock, T.B.B.; Simonsen, R. \& Sims, P.A. (1979): An amended terminology for the siliceous components of the diatom cell. - Nova Hedwigia, Beih. 64: 513533.

Rougerie, F.; Fichez, R. \& DéJardin, P. (1997): Geomorphology and hydrogeology of selected islands of French Polynesia: Tikehau (atoll) and Tahiti (barrier reef). - In: VACHER, H.L. \& QuinN, T. (eds): Geology and Hydrogeology of Carbonate Islands. Developments in sedimentology. - pp. 475502, Elsevier, Amsterdam.

Rougerie, F. \& Wauthy, B. (1986): Le concept d'endoupwelling dans le fonctionnement des atolls-oasis. - Oceanol. Acta 9: 133-148.

Round, F.E.; Crawford, R.M. \& Mann, D.G. (1990): The diatoms. Biology \& morphology of the genera. -747 pp., Cambridge University Press, Cambridge.

Schmidt, A. (1894): Atlas der Diatomaceenkunde. - pl. 189190, Leipzig.

SourniA, A. (1977): Analyse et bilan de la production primaire dans les récifs coralliens. - Ann. Inst. Océanogr. Nelle Ser. 53: 47-74.

Sournia, A. \& RicARD, M. (1975): Phytoplankton and primary productivity in Takapoto atoll, Tuamotu islands. - Micronesica 11: 159-166.

Sournia, A. \& Ricard, M. (1976): Données sur l'hydrologie et la productivité du lagon d'un atoll fermé (Takapoto, îles Tuamotu). - Vie \& Milieu, sér. B 26: 243-279.

Stanca, E.; Roselli, L.; Durante, G.; Seveso, D.; Galli, P. \& BASSET, A. (2013): Checklist of phytoplankton species in the Faafu atoll (Republic of Maldives). TWB, Transit. - Waters Bull. 7(2): 133-144 ISSN 1825-229X, DOI 10.1285/i1825229Xv7n2p133.

Suzuki, H.; Nagumo, T. \& TanaKa, J. (2000): Epiphytic diatoms on a red alga Ceramium tenerrimum (Martens) Okamura from Kanagawa pref. - Japan. Bull. Aoyama Gakuin Senior High School 23: 13-25.

Suzuki, H.; Nagumo, T. \& TanaKa, J. (2008): Morphology and taxonomy of Cocconeis subtilissima Meister (Bacillariophyceae) and two closely related taxa from the coastal waters of Japan. - J. Jpn. Bot. 83: 269-279.

TаватA, S. (1975): The general circulation of the Pacific Ocean. Part I: Circulation and Volume. - Transports Atmosphere 13: 133-168.

(C) Czech Phycological Society (2014)

Received May 19, 2014

Accepted June 5, 2014 